\title{
Introduction to the Special Issue \\ on Women in Pennsylvania Politics
}

JENNIE SWEET-CUSHMAN

Special Issue Editor

everal years ago, as assistant director of the Pennsylvania Center for Women and Politics, I interviewed more than a dozen women serving in Pennsylvania's General Assembly about the role women play in the legislature. Without exception and across region and party these women believe their presence as women matters tremendously in the legislative process, to the legislative agenda, and for legislative outcomes. And they are right; women's work in the Pennsylvania legislature leads to more advocacy for women's issues, more collaboration among women, greater bipartisan effort, and-ultimately-more bills signed into law (Sweet-Cushman, 2020).

What these public servants have always known about their ability to both represent a diverse set of women's interests well and work effectively as legislators is starting to become more visible to the general public. On the heels of the 2016 presidential election came a period of hyper-focus on gender equality, women's issues, and female candidates running for office at every level. While the phenomenon benefitted primarily Democratic women, the 2018 midterm election was record breaking for women running and winning across the United States. Women now hold $25.2 \%$ of the seats in the U.S. Congress: 26 seats in the U.S. Senate and 101 in the U.S. House of Representatives, a historic record for both chambers (Center for American Women and Politics 2020). At

COMMONWEALTH, Volume 21, Issue 1 (2021). (C) 2021 The Pennsylvania Political Science Association. ISSN 2469-7672 (online). http://dx.doi.org/10.15367/com.v21i1.285. All rights reserved. 
the state level, nine women now serve as governors (tying the previous record) and hold $29.2 \%$ of the states' legislative seats.

Nowhere were the increases as dramatic as in Pennsylvania, a state ranked 49 th overall in women's representation prior to the 2018 election (Represent Women 2017). The statistics read like a laundry list of dismal attributes. Pennsylvania has (still) never elected a woman to the U.S. Senate or as governor. The 114th and 115th Congresses had no women in the state's 20 -member congressional delegation. The state's legislature ranked 39th in the nation for women's representation (Center for American Women and Politics 2018), with almost no women in leadership on either side of the aisle. Of the state's 67 counties, 32 of them fail to have even one woman serving on its legislative body (Pennsylvania Center for Women and Politics 2016). School boards in Pennsylvania are comprised of only 37\% women (Pennsylvania Center for Women and Politics 2014), whereas nationally women have been near gender parity for many years.

However, the 2018 election represented something of a "pink wave" (for lack of a better term). The General Assembly saw notable increases. Women now hold 13 seats of the 50-member State Senate and 54 seats in the 203-member State House chamber-26\% of the state legislature, an all-time high. In another historic first, four women (all Democrats) were elected to the state's congressional delegation. More women than ever ran for political office in the state, and more women than ever won political office. Nonetheless, in virtually every type of political office in the state, men continue to hold about $80 \%$ of the seats.

While theories abound as to why women are generally underrepresented in American politics, why it is so profoundly bad in Pennsylvania is another question altogether. Some answers can be found on the institutional level, such as the daunting travel distance to Harrisburg (Silbermann 2015) and the professionalism and full-time operation of the General Assembly (Thomas 1996). Some blame likely belongs with the state's traditional political culture (Hill 1981) and, in particular, the parties' traditional political culture (Freeman 1986), which certainly contributes to: (1) issues surrounding demand for female candidates (Sanbonmatsu 2002; Crowder-Meyer 2013; also both Brown and Weikert in this issue); (2) the likelihood that women in the state see themselves as potential candidates (Fox and Lawless 2005; SweetCushman 2018); and (3) whether voters have an affinity for female candidates (Sanbonmatsu 2006; Dolan 2014; Bauer 2015).

This issue of COMMONWEALTH recognizes that gender is increasingly important in Pennsylvania politics for voters, party elites, candidates, and the actions of our elected officials. We explore each of these aspects in this issue. 
Sarah Niebler and A. Lanethea Mathews-Schultz analyze Pennsylvania exit poll data they collected in both 2016 and 2018 to explore patterns in voting decision-making. They find, much like broader research on vote choice, that political party is the major driver of attitudes toward female candidates. However, more nuanced attitudes about women in politics are conditioned by gender, with women of both parties being more likely than men to see gender as playing a role in women's political representation. This research provides rich insight into what drives Pennsylvania voters and how their views of politics may be influenced by their gender and their views of women in politics.

One of their findings is that there is significant belief ( $30 \%$ or more) in Pennsylvania's electorate, across party and gender, that female candidates get less support from party leaders. Dana Brown tackles precisely this problem in her qualitative exploration of party leaders' approach to candidate recruitment. We know from previous research that candidate recruitment is frequently a gendered selection process. Across more than 30 interviews with county party chairs and vice chairs of both the Republican and Democratic parties, Brown identifies a mixed approach to recruitment, all of which predominately leads to the recruitment of male candidates. As she writes, "Only one county party chair spoke of intentionally including women as part of the pool of candidates" (this issue, 48).

How then did the 2018 midterm elections result in such a marked increase in the number of women running (and winning) political office in the Commonwealth, and is it likely to continue into 2020 and beyond? Joshua Weikert interviewed female candidates who sought political office in 2018 to get a sense of how they were recruited, what their motivations were, and how persistent they were. In doing so, he hopes to determine whether the "pink wave" of 2018 was another singular "year of the woman" (like 1992), or a continuing trend in Pennsylvania politics. His findings are encouraging. The candidates-both successful and unsuccessful-whom he interviewed reported some success in volunteering as candidates or being recruited by the party and a marked intent to stay engaged in politics by recruiting others or running again in the future.

Weikert's findings are most encouraging given the compelling evidence that gender parity in representation is important from a democratic perspective: when people feel they are represented in their government, they are more likely to trust that government (Mansbridge 1999; Gay 2002). Given the historic low of American trust in government, a mere $17 \%$ of citizens according to Pew Research Center (2019), increased representation of women must be perceived as a move in the right direction. There are also more applied reasons why women's underrepresentation may be of concern. When women's voices 
aren't part of the conversation, public policy is often created that doesn't consider their unique lived experiences. Furthermore, women frequently bring a unique leadership and governance style to their roles as elected officials (Eagly, Johannesen-Schmidt, and Van Engen 2003; Schneider et al. 2016). The legislators I interviewed in the General Assembly all agreed that women approached their jobs in a distinct, positive way (Sweet-Cushman 2020).

Benjamin Melusky in his article offers a high-profile example of precisely why women's representation can have broad and meaningful consequences in the realm of public policy. Drawing on gender role socialization theory, Melusky demonstrates how the presence of women, with their differently socialized legislating style, impacts the state budget process. He finds that this frequently divisive battle in the state legislature is made easier by compromise-inclined female legislators and concludes that the annual process would benefit from the continued addition of female legislators to the body. Presumably, so too would other lawmaking processes.

It bears repeating: never in the Commonwealth's history has there been a female governor or U.S. senator. That should be shocking to those who call the Keystone State home. The exit polls conducted by Niebler and MathewsSchultz reveal just how ill-informed voters are about women's underrepresentation-only $8 \%$ accurately identified how many women were in the state's congressional delegation. The authors included in this issue draw attention to the obstacles to electing more women, particularly the role of Pennsylvania's strong political parties. As Niebler and Mathews-Schultz demonstrate, that partisan attachment strongly influences vote choice. If, as Brown finds, women are typically not inherently part of party recruitment processes, there will be fewer women on the partisan ballot to choose from when voters approach with their partisan lens. Demand for female candidates is unlikely to change.

However, as Weikert reveals, supply of female candidates very well might change. Many of the 2018 candidates who ran initiated their own candidacies, effectively working around the gendered system of recruitment that Brown's interviews describe. While it isn't clear whether these women received the type of support they needed from their party after they initiated their candidacies, they were clearly very successful in 2018 and, as Weikert reports, they remain motivated to promote other candidates (women candidates, perhaps) and to stay engaged themselves.

Ultimately, electing more women just for the sake of electing more women isn't necessarily anyone's goal. The broader point is that when women are underrepresented, women's needs are underrepresented in policymaking and women's strengths in governance are also underrepresented. Melusky gives 
us but one example, the state legislative budget process, in which all Pennsylvanians benefit when women are at the table, but it is not hard to imagine that more collaborative, collegial, and bipartisan environments would benefit other policy areas as well. Future elections may reveal whether Pennsylvania voters come to agree.

\section{REFERENCES}

Bauer, Nichole M. 2015. "Emotional, Sensitive, and Unfit for Office? Gender Stereotype Activation and Support Female Candidates.” Political Psychology 36 (December): 691-708.

Center for American Women and Politics. 2018. "Women in State Legislatures, 2018." Available at https://cawp.rutgers.edu/women-state-legislature-2018.

— 2020. "Women in the U.S. Congress, 2020.” Available at https://cawp.rutgers.edu/ women-us-congress-2020.

Crowder-Meyer, Melody. 2013. "Gendered Recruitment without Trying: How Local Party Recruiters Affect Women's Representation.” Politics \& Gender 9 (December): 390413.

Dolan, Kathy. 2014. When Does Gender Matter?: Women Candidates and Gender Stereotypes in American Elections. New York: Oxford University Press.

Eagly, Alice H., Mary C. Johannesen-Schmidt, and Marloes L. Van Engen. 2003. “Transformational, Transactional, and Laissez-Faire Leadership Styles: A Meta-Analysis Comparing Women and Men." Psychological Bulletin 129 (July): 569-591.

Fox, Richard L., and Jennifer L. Lawless. 2005. "To Run or Not to Run for Office: Explaining Nascent Political Ambition.” American Journal of Political Science 49 (July): 642-659.

Freeman, Jo. 1986. "The Political Culture of the Democratic and Republican Parties." Political Science Quarterly 101 (3): 327-356.

Gay, Claudine. 2002. "Spirals of Trust? The Effect of Descriptive Representation on the Relationship Between Citizens and Their Government." American Journal of Political Science 46 (October): 717-732.

Hill, David B. 1981. "Political Culture and Female Political Representation." The Journal of Politics 43 (February): 159-168.

Mansbridge, Jane. 1999. "Should Blacks Represent Blacks and Women Represent Women? A Contingent 'Yes." The Journal of Politics 61 (August): 628-657.

Pennsylvania Center for Women and Politics. 2014. "Fact Sheet."

- 2016. "Fact Sheet."

Pew Research Center. 2019. Public Trust in Government: 1958-2019. Available at https:// www.people-press.org/2019/04/11/public-trust-in-government-1958-2019/.

Represent Women. 2017. "Gender Parity Index." Available at https://www.represent women.org/gender_parity_index.

Sanbonmatsu, Kira. 2002. "Gender Stereotypes and Vote Choice." American Journal of Political Science 46 (2002): 20-34.

- 2006. “Do Parties Know that 'Women Win'? Party Leader Beliefs about Women's Electoral Chances." Politics \& Gender 2 (December): 431-450.

Schneider, Monica C., Mirya R. Holman, Amanda B. Diekman, and Thomas McAndrew. 2016. "Power, Conflict, and Community: How Gendered Views of Political Power Influence Women's Political Ambition.” Political Psychology 37 (August): 515-531. 
Silbermann, Rachel. 2015. "Gender Roles, Work-Life Balance, and Running for Office." Quarterly Journal of Political Science 10 (June): 123-153.

Sweet-Cushman, Jennie. 2018. "Where Does the Pipeline Get Leaky? The Progressive Ambition of School Board Members and Personal and Political Network Recruitment." Politics, Groups, and Identities. doi: 10.1080/21565503.2018.1541417.

_ 2020. "Gendered Legislative Effectiveness in State Legislatures: The Case of Pennsylvania.” In Politicking While Female: The Political Life of Women, ed. Nichole Bauer. Baton Rouge: Louisiana State University Press.

Thomas, Sue. 1996. "Why Gender Matters: The Perceptions of Women Officeholders." Women \& Politics 17 (1): 27-53.

Jennie Sweet-Cushman is an associate professor of political science at Chatham University, where from 2013 to 2019 she also served as the assistant director of the Pennsylvania Center for Women and Politics and was awarded the Buhl Professorship in 2020. Her research focuses on women's political ambition and representation in the United States as well as gender equity in academia. Her recent work has appeared in PS: Political Science \& Politics; Politics, Groups, and Identities; and Politics and the Life Sciences; and her ongoing project on the first-in-the-nation majority-female Nevada state legislature was awarded the 2019 Carrie Chapman Catt Prize for research in women and politics. She was the 2020 recipient of the APSA CQ Press Award for Teaching Innovation. 